\title{
A Photo-Based Environmental History of the Use of Climbing Plants in Central Oxford, UK
}

\author{
Mary J. Thornbush \\ School of Geography, Earth and Environmental Sciences, University of Birmingham, \\ Birmingham, UK \\ Email: m.thornbush@bham.ac.uk
}

Received June 24, 2013; revised July 26, 2013; accepted August 23, 2013

Copyright (C) 2013 Mary J. Thornbush. This is an open access article distributed under the Creative Commons Attribution License, which permits unrestricted use, distribution, and reproduction in any medium, provided the original work is properly cited.

\begin{abstract}
This paper examines environmental change associated with climbing plants (ivy/creeper) on several historical buildings in central Oxford using archival photographs. ViewFinder from English Heritage was used to access the photo archives in an advanced search of the area of "Oxford" and in the county of "Oxfordshire". The study includes a variety of buildings, including colleges, churches, chapels, asylums, inns/hotels, factories, a brewery, pubs, a castle as well as architectural elements, such as doorways, cloisters, gates, and walls. The findings reveal that a majority of photographs denoted ivy-/creeper-clad buildings (in nearly 53\% of photographs found mostly in the Taunt collection). The greatest abundance of climbing plants was found in the 1880s followed by the 1900s. A further examination of University colleges is warranted due to the earlier and more frequent appearance of ivy/creeper on these buildings.
\end{abstract}

Keywords: Ivy; Creeper; Historical Buildings; Photo Archives; ViewFinder

\section{Introduction}

Historical photographs provide an abundant resource to understand environmental change as part of urban geographical studies. Urban greening has varied throughout the photo archival record and an analysis is presented here for Oxford, UK. More specifically, climbing plants (ivy/creeper) are tracked historically in a photo archival study that encompasses not only Oxford colleges, but also other non-University buildings located in the city center. The purpose of this research is to establish a clearer (broader or contextual) understanding of the use of ivy/creeper in an attempt to ascertain the reason for its appearance through temporal sequences of change captured by photographs taken at various locations. This contribution denotes geography from a combined human-physical perspective, which is evident in environmental geography. More specifically, it focuses on human-environment interactions and, hence, partakes of an environmental geomorphology, as demonstrated in previous similar (geographical) publications (e.g., [1]).

Because of the cross-disciplinary scope of addressing an environmental history of ivy/creeper, (to the author's knowledge) there are no precedent published spatialtemporal studies for Oxford that examine ivy/creeper through the archival record, except for recent works in progress by the author. The most relevant published work is a short "Sources" piece published in the journal of Environmental History on the use of postcards to track environmental change of ivy/creeper cover at Oxford colleges [2]. There is also an archival study conducted at Magdalen College, which examined the photo archival record in combination with historical records of traffic congestion at Magdalen Bridge [3]. In this study, the authors were more interested in investigating stone soiling and decay along the High Street frontage in connection with traffic pollution rather than the use of climbing plants, as in the current study. They did, however, include a photograph from the late 19th century (from circa 1896-1899, in their Figure 3) that clearly portrays ivy/creeper on Magdalen Tower. Previous to this, authors (e.g., [4]) also presented some case studies, as of the Bodleian Library from the Catte Street front in 1904, 1939,1952 , and 1993 as well as the Tower of the Five Orders in circa 1880, circa 1900, 1956, and 1993; the Ashmolean Museum in 1882, 1960, 1963, 1976, and 1993; and Wadham College from the Parks Road front in circa $1820,1885,1956$, early 1960s, and 1993. Here, the author saw the potential of archival evidence, especially photographs, as providing an objective framework for the study of the history of stone decay. Subsequently, archi- 
val studies have been conducted using historical photographs from Trinity College (e.g., [5], who examined blistering based on archival photographs, including group photographs, such as of rowing eight from the summer of 1882) and also from Pembroke College, Oxford [6]. Other researches by these authors have focused on stone decay in general rather than on a biological cover, with work that utilized photographic surveying in order to capture cross-temporal and -spatial change (e.g., [7,8]). Much of this work was quantitative and aimed to measure (indoor and outdoor) soiling and decay of limestone (e.g., [9-13]). Most recently, a limestone weathering scale was developed [14] and applied [15] that also accounts for the impacts of a vegetation cover (including ivy/creeper) on limestone surfaces. Moreover, there have been further applications of quantitative photography to measure the greening of stone surfaces by algae [16] and provide an overview of Oxford studies written within a photogeomorphological approach [17]. Finally, the strengths and limitations of using climbing plants on historical stone (for heritage bioconservation) have been evaluated most recently [18].

The interest of climbing plants on old walls stems from current feelings of gardeners, which tend to be disparate-either for or against the use of ivy in particular. Indeed, looking around much of central Oxford, it is difficult to find evidence of climbing plants (in particular) on historical buildings today, except perhaps on boundary walls (such as at Trinity and Worcester Colleges) or unmaintained remains (such as at Rewley Abbey and the City Wall). However, it should be noted that there are exceptions and, for instance, ivy/creeper (especially creeper) can be seen growing on some buildings, even today at Trinity and Pembroke Colleges. There is a recent interest in the use of ivy (Hedera helix) and, in 2006, English Heritage funded a project that addressed ivy on walls (The "Ivy on walls - biodeterioration or bioprotection?" summarized in the poster: http:/www.srs.ac.uk/ scienceandheritage/presentations/Ivy_poster.pdf. More details can be obtained from the project webpage: http://www.geog.ox.ac.uk/research/arid-environments/ru bble/ivy/). This project considered the maintenance of ivy and the current practice of gardeners at colleges and other locations in England. The study does not, however, consist of an in-depth investigation into the historical record for an environmental history perspective of the appearance of ivy that may make an important contribution to an informed understanding of past use.

\section{Methods}

The overarching aim of the current study is to track the use of ivy/creeper on buildings in Oxford using historical photographs from the digital photo archive ViewFinder maintained by English Heritage. Including non- college historical buildings allows for a consideration of use and practice in central Oxford (in the "town") outside properties belonging to the University of Oxford (the "gown"). Such an approach lends to a further understanding of environmental history outside the University domain and may help to isolate trends in the record that may not be apparent by studying only colleges (e.g., [2,3,6]). There are three study objectives as follows: 1) to use View Finder to search for historical photographs; 2) to identify photographs in the study area that contain ivy/creeper; and 3) to examine any temporal patterns in the appearance of ivy/creeper. To this end, single, ground-level black-and-white photographs with a single year (known) date were examined on a present/ absent basis.

Historical photographs were searched in an image gallery in ViewFinder of the National Monuments Record in the public archive of English Heritage (webpage: http://viewfinder.english-heritage.org.uk/home.asp?JS=T rue). An advanced search of the image gallery was conducted for the county of "Oxfordshire", in the area of "Oxford" (no other fields, including a particular collection, were specified). Only photographs depicting the outside (or exterior) of buildings were examined in this study, which consisted of colleges (including doorways, cloisters, gateways), churches, chapels, asylums, inns/ hotels, factories, brewery, pubs, a castle, and walls, such as the City Wall and boundary walls. The following were excluded from the quantification: building interiors, gardens (e.g., the Botanic Garden), memorials, cemeteries, shops, streets/ roads, locations outside central Oxford, rooftop and oblique views, artistic works (e.g., photographs of engravings), replicates (but not multiples), split images, and color images. Specific attention was paid to any climbing plants visible on the exterior of buildings, but photographs missing these were also considered in this investigation for a comparison of ivy-/creeper-clad versus ivy-/creeper-free buildings and building components. Buildings comprised both University and nonUniversity properties with and without ivy/creeper located in the Oxford city center.

\section{Results}

A majority of photographs were derived from the Henry W. Taunt (1860-1922) collection, comprising black and white images of Oxford. Others have photographed Oxford, including Eric de Mare (1945-1960), Nathaniel Lloyd (1920-1925), in the early 1900s: Newton, Rupert Potter, and John Maltby, and in the late 1800s: H. Bedford Lemere (1883). However, Taunt's collection is extensive and comprises some 4435 images relevant to this investigation. In addition to Henry Taunt's photographs, this study also consists of photography from the Alfred Newton and Son collection as well as the Rupert Potter 
and the Nathaniel Lloyd collections. Out of a total of 4634 images that resulted from the advanced search, 1123 were relevant images (as specified in the Methods); of these, $596 \mathrm{had}$ ivy/creeper cover and slightly fewer images (527) were without any ivy/creeper (Figure 1). When counts are taken as a proportion of the total at each location (Figure 2), there is an overall 53\% of buildings with an ivy/creeper cover. The greatest proportion of ivy/creeper is evident in the $1880 \mathrm{~s}(60 \%)$ followed by the 1900 s $(53 \%)$. As a measure of the grand total (of 1,123 ), ivy/creeper cover was greatest in the 1880 s $(17 \%$ compared to $11 \%$ without any ivy/creeper cover) with an almost equal representation (of with ivy/creeper versus no ivy/creeper) in other decades (Figure 3).

A wide variety of University and non-University buildings are represented in this study that are listed in Table 1 (note that names of locations used throughout this paper are based on the spelling found in the View-

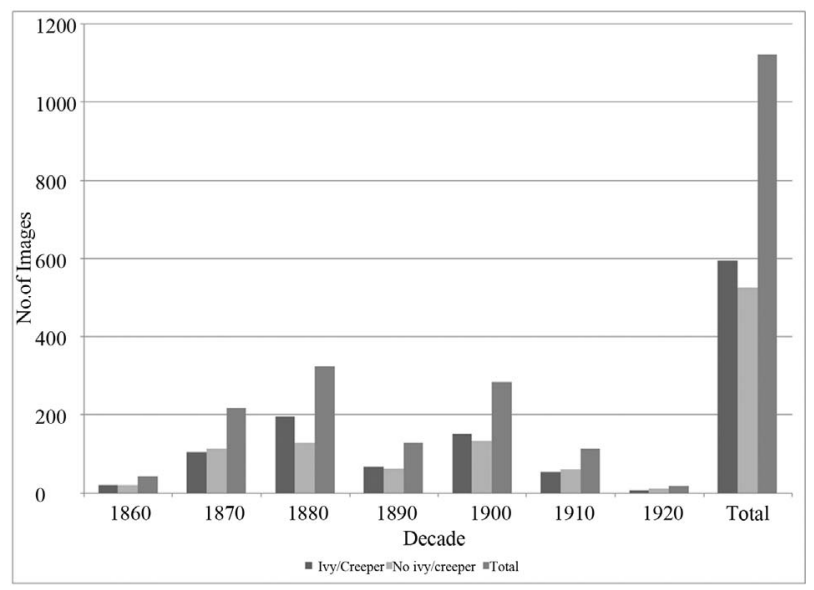

Figure 1. Counts of images from the View Finder archive based on the appearance of climbing plants (ivy/creeper) on building exteriors.

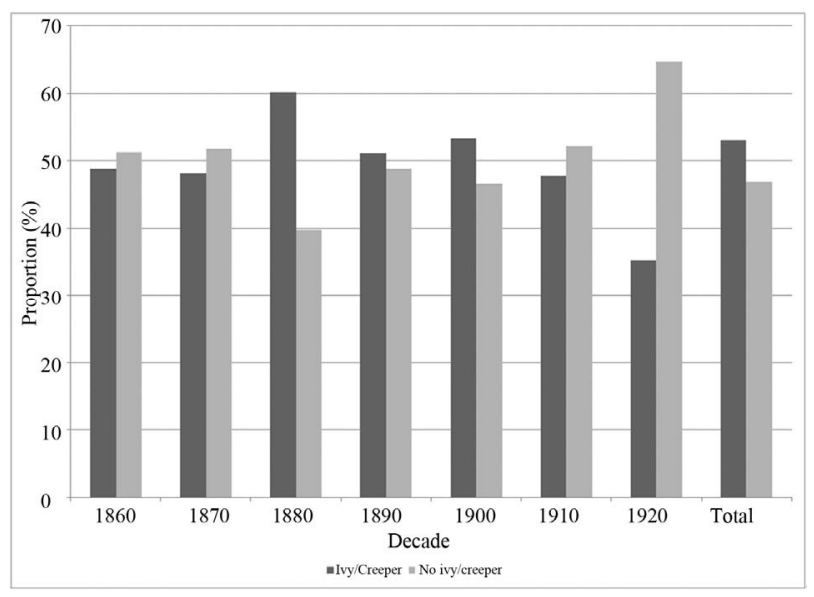

Figure 2. The decadal proportion of images conveying the appearance of climbing plants (ivy/creeper) on building exteriors.

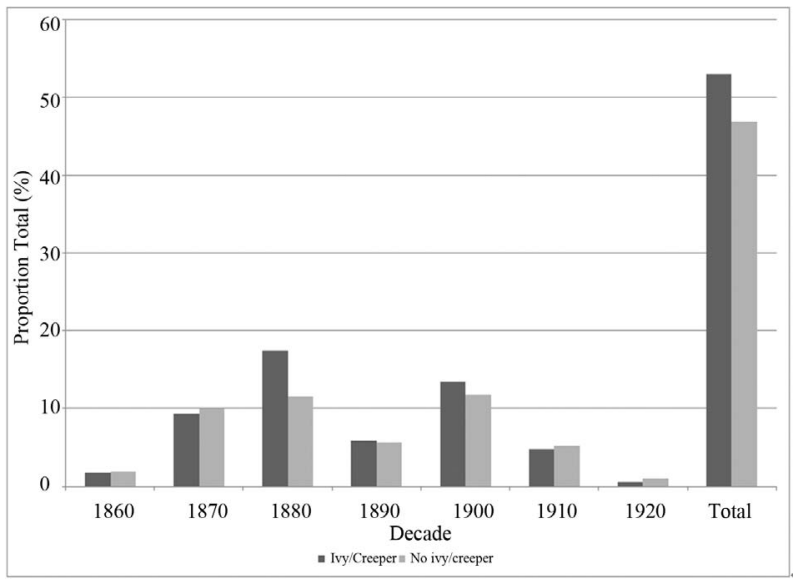

Figure 3. The decadal proportion of images conveying the appearance of climbing plants (ivy/creeper) on building exteriors according to the total relevant images (of 1123) used from ViewFinder.

Finder database). A total of 64 buildings (about 59\%) belonged to the "town" and 44 properties (about $41 \%$ ) of the University of Oxford "gown" locations are represented. There are 20 instances of 100\% ivy/creeper cover (or about $19 \%$ of the total 108 locations) and 47 instances of $100 \%$ no ivy/creeper cover (or about $44 \%$ of the 108 locations). Those locations with $100 \%$ ivy/ creeper cover in all images contained in this photo archive include halls, manors, and great houses (e.g., Bishop King's Palace, City Gaol, Frewin Hall, Grandpoint Hall, Judges Lodges, Medley Manor, Oxford Union, Radcliffe Infirmary, St Giles House, St Marys Hall, and Wycliffe Hall), some churches and chapels (e.g., Holywell Chapel, New Road Baptist Chapel, St Aldates Church, St Aloysius Church, St Michaels Church, St Peter Le Bailey Church, and St Thomas Church), and some University colleges (e.g., Brasenose College and Lady Margaret Hall).

Locations that are normally devoid of any climbing plants are non-University properties, including most churches, museums, hotels, pubs, and civic buildings. However, not all University buildings had an ivy/creeper cover, such as the Agricultural Sciences Department, Clarendon Building, Indian Institute, Manchester College, Radcliffe Camera, Radcliffe Sciences Library, St Peters College, St Stephens House, and Taylorian Institute. Nevertheless, University colleges most often appeared with climbing plants (e.g., All Souls, Balliol, Corpus Christi, Keble, Lincoln, Magdalen, Merton, New, Pembroke, Somerville, St Edmund Hall, St Hildas, Trinity, University, and Worcester Colleges). Of the 28 University colleges examined here, only two colleges (namely, Manchester and St Peters Colleges) did not have any ivy/ creeper cover between 1860 and 1925. Out of $861 \mathrm{im}-$ ages of University colleges in this investigation, 495 (or about 57\%) showed ivy/creeper and 366 (or about 43\%) 
Table 1. Counts and proportions based on locations represented in this study.

\begin{tabular}{|c|c|c|c|c|c|}
\hline Location & Ivy/Creeper & No Ivy/Creeper & Total & \% Ivy/Creeper & \% No Ivy/Creeper \\
\hline 7 Princes Street & 0 & 1 & 1 & 0 & 100 \\
\hline 17 Broad Street & 0 & 1 & 1 & 0 & 100 \\
\hline 65 Holywell Street & 2 & 1 & 3 & 67 & 33 \\
\hline Agricultural Sciences Department & 0 & 1 & 1 & 0 & 100 \\
\hline All Saints Church & 0 & 2 & 2 & 0 & 100 \\
\hline All Souls College & 19 & 10 & 29 & 66 & 34 \\
\hline Apsley Paddox & 0 & 6 & 6 & 0 & 100 \\
\hline Ashmolean Museum & 0 & 4 & 4 & 0 & 100 \\
\hline Balliol College & 37 & 20 & 57 & 65 & 35 \\
\hline Bear Inn & 0 & 1 & 1 & 0 & 100 \\
\hline Bishop King's Palace & 1 & 0 & 1 & 100 & 0 \\
\hline Black Hall & 0 & 1 & 1 & 0 & 100 \\
\hline Blue Pig Public House & 0 & 1 & 1 & 0 & 100 \\
\hline Bodleian Library & 3 & 13 & 16 & 19 & 81 \\
\hline Brasenose College & 10 & 34 & 44 & 23 & 77 \\
\hline Britannia Inn & 1 & 0 & 1 & 100 & 0 \\
\hline Carfax Clock & 0 & 1 & 1 & 0 & 100 \\
\hline Central Girls School & 0 & 1 & 1 & 0 & 100 \\
\hline Christ Church Cathedral & 11 & 3 & 14 & 79 & 21 \\
\hline Christ Church College & 7 & 23 & 30 & 23 & 77 \\
\hline City Gaol & 0 & 1 & 1 & 0 & 100 \\
\hline City Walls & 4 & 0 & 4 & 100 & 0 \\
\hline Clarendon Building & 0 & 2 & 2 & 0 & 100 \\
\hline Corpus Christi College & 23 & 16 & 39 & 59 & 41 \\
\hline County Hall & 0 & 1 & 1 & 0 & 100 \\
\hline Eastgate Hotel & 0 & 5 & 5 & 0 & 100 \\
\hline Examination Schools & 0 & 5 & 5 & 0 & 100 \\
\hline Exeter College & 12 & 22 & 34 & 35 & 65 \\
\hline Frank Cooper's Works & 0 & 2 & 2 & 0 & 100 \\
\hline Frewin Hall & 3 & 0 & 3 & 100 & 0 \\
\hline Golden Cross Hotel & 0 & 1 & 1 & 0 & 100 \\
\hline Grandpoint Hall & 1 & 0 & 1 & 100 & 0 \\
\hline Hertford College & 11 & 17 & 28 & 39 & 61 \\
\hline Holywell Chapel & 1 & 0 & 1 & 100 & 0 \\
\hline Indian Institute & 0 & 3 & 3 & 0 & 100 \\
\hline Jesus College & 6 & 6 & 12 & 50 & 50 \\
\hline
\end{tabular}




\begin{tabular}{|c|c|c|c|c|c|}
\hline Jolly Farmers Inn & 0 & 1 & 1 & 0 & 100 \\
\hline Judges Lodgings & 1 & 0 & 1 & 100 & 0 \\
\hline Keble College & 9 & 6 & 15 & 60 & 40 \\
\hline Kemp Hall Police Station & 0 & 3 & 3 & 0 & 100 \\
\hline Lady Margaret Hall & 2 & 0 & 2 & 100 & 0 \\
\hline Lincoln College & 16 & 7 & 23 & 70 & 30 \\
\hline Magdalen College & 98 & 46 & 144 & 68 & 32 \\
\hline Magdalen College School & 0 & 1 & 1 & 0 & 100 \\
\hline Manchester College & 0 & 2 & 2 & 0 & 100 \\
\hline Mansfield College & 2 & 5 & 7 & 29 & 71 \\
\hline Medley Manor & 2 & 0 & 2 & 100 & 0 \\
\hline Merton College & 38 & 21 & 59 & 64 & 36 \\
\hline Morrells Brewery & 0 & 1 & 1 & 0 & 100 \\
\hline New College & 38 & 19 & 57 & 67 & 33 \\
\hline New Road Baptist Chapel & 1 & 0 & 1 & 100 & 0 \\
\hline Old Ashmolean Museum & 0 & 2 & 2 & 0 & 100 \\
\hline Old Gate House Public House & 0 & 1 & 1 & 0 & 100 \\
\hline Old University Hall & 4 & 2 & 6 & 67 & 33 \\
\hline Oriel College & 8 & 11 & 19 & 42 & 58 \\
\hline Oxford Castle & 6 & 5 & 11 & 55 & 45 \\
\hline Oxford Times Offices & 0 & 1 & 1 & 0 & 100 \\
\hline Oxford Union & 1 & 0 & 1 & 100 & 0 \\
\hline Pembroke College & 12 & 7 & 19 & 63 & 37 \\
\hline Pusey House & 0 & 2 & 2 & 0 & 100 \\
\hline Queen's College & 5 & 13 & 18 & 28 & 72 \\
\hline Radcliffe Camera & 0 & 3 & 3 & 0 & 100 \\
\hline Radcliffe Infirmary & 3 & 0 & 3 & 100 & 0 \\
\hline Radcliffe Science Library & 0 & 1 & 1 & 0 & 100 \\
\hline Randolph Hotel & 1 & 1 & 2 & 50 & 50 \\
\hline Roebuck Hotel & 0 & 5 & 5 & 0 & 100 \\
\hline Ruskin College & 0 & 1 & 1 & 0 & 100 \\
\hline Sheldonian Theatre & 1 & 3 & 4 & 25 & 75 \\
\hline Somerville College & 2 & 1 & 3 & 67 & 33 \\
\hline St Aldates Church & 2 & 0 & 2 & 100 & 0 \\
\hline St Aloysius Church & 1 & 0 & 1 & 100 & 0 \\
\hline St Andrew's Church & 0 & 1 & 1 & 0 & 100 \\
\hline St Barnabas' Church & 0 & 1 & 1 & 0 & 100 \\
\hline
\end{tabular}




\section{Continued}

\begin{tabular}{|c|c|c|c|c|c|}
\hline St Bartholomew's Chapel & 0 & 3 & 3 & 0 & 100 \\
\hline St Bartholomew's Hospital & 0 & 1 & 1 & 0 & 100 \\
\hline St Cross Church & 2 & 3 & 5 & 40 & 60 \\
\hline St Ebbes Church & 1 & 1 & 2 & 50 & 50 \\
\hline St Edmund and St Frideswides Church & 0 & 2 & 2 & 0 & 100 \\
\hline St Edmund Hall & 9 & 2 & 11 & 82 & 18 \\
\hline St George's Chapel & 0 & 1 & 1 & 0 & 100 \\
\hline St Giles' Church & 1 & 8 & 9 & 11 & 89 \\
\hline St Giles House & 2 & 0 & 2 & 100 & 0 \\
\hline St Hildas College & 8 & 1 & 9 & 89 & 11 \\
\hline St Johns College & 22 & 26 & 48 & 46 & 54 \\
\hline St Martins Church & 0 & 8 & 8 & 0 & 100 \\
\hline St Mary Magdalens Church & 1 & 14 & 15 & 7 & 93 \\
\hline St Mary the Virgin Church & 9 & 4 & 13 & 69 & 31 \\
\hline St Marys Hall & 1 & 0 & 1 & 100 & 0 \\
\hline St Matthews Church & 0 & 2 & 2 & 0 & 100 \\
\hline St Michaels Church & 7 & 0 & 7 & 100 & 0 \\
\hline St Paul's Church & 0 & 1 & 1 & 0 & 100 \\
\hline St Peter in the East Church & 6 & 3 & 9 & 67 & 33 \\
\hline St Peter Le Bailey Church & 1 & 0 & 1 & 100 & 0 \\
\hline St Peters College & 0 & 1 & 1 & 0 & 100 \\
\hline St Philip and St James Church & 2 & 1 & 3 & 67 & 33 \\
\hline St Stephens House & 0 & 1 & 1 & 0 & 100 \\
\hline St Thomas Church & 3 & 0 & 3 & 100 & 0 \\
\hline Stones Almshouses & 0 & 1 & 1 & 0 & 100 \\
\hline Taylorian Institute & 0 & 3 & 3 & 0 & 100 \\
\hline Town Hall & 0 & 6 & 6 & 0 & 100 \\
\hline Trinity College & 21 & 17 & 38 & 55 & 45 \\
\hline Turf Tavern & 0 & 2 & 2 & 0 & 100 \\
\hline University College & 25 & 10 & 35 & 71 & 29 \\
\hline University Museum & 2 & 3 & 5 & 40 & 60 \\
\hline Wadham College & 6 & 21 & 27 & 22 & 78 \\
\hline Warneford Asylum & 5 & 1 & 6 & 83 & 17 \\
\hline Worcester College & 49 & 2 & 51 & 96 & 4 \\
\hline Wycliffe Hall & 8 & 0 & 8 & 100 & 0 \\
\hline Total & 596 & 527 & 1123 & 53 & 47 \\
\hline
\end{tabular}


were devoid of climbing plants. This represents a total of almost $77 \%$ of the total record of 1123 examined in this study, including about $44 \%$ that showed climbing plants and $33 \%$ that excluded them.
Table 2 presents a time-line (seriation) of the appear ance of ivy/creeper on building exteriors (with University buildings emboldened). Buildings with a consistent ivy/ creeper cover include: All Souls College, Balliol College,

Table 2. Seriation of the appearance of ivy/creeper on building exteriors in central Oxford from the ViewFinder archive. Black cells represent the appearance of ivy/creeper and gray cells show where there is a lack of ivy/creeper. University properties are emboldened.

\begin{tabular}{|c|c|c|c|c|c|c|c|}
\hline Location & 1860 & 1870 & 1880 & 1890 & 1900 & 1910 & 1920 \\
\hline \multicolumn{8}{|l|}{7 Princes Street (1) } \\
\hline \multicolumn{8}{|l|}{65 Holywell Street (2) } \\
\hline \multicolumn{8}{|l|}{65 Holywell Street (1) } \\
\hline \multicolumn{8}{|l|}{ Agricultural Sciences Department (1) } \\
\hline \multicolumn{8}{|l|}{ All Saints Church (2) } \\
\hline \multicolumn{8}{|l|}{ All Souls College (19) } \\
\hline \multicolumn{8}{|l|}{ All Souls College (10) } \\
\hline \multicolumn{8}{|l|}{ Apsley Paddox (6) } \\
\hline \multicolumn{8}{|l|}{ Ashmolean Museum (4) } \\
\hline \multicolumn{8}{|l|}{ Balliol College (37) } \\
\hline \multicolumn{8}{|l|}{ Balliol College (20) } \\
\hline \multicolumn{8}{|l|}{ Bear Inn (1) } \\
\hline \multicolumn{8}{|l|}{ Bishop King's Palace (1) } \\
\hline \multicolumn{8}{|l|}{ Black Hall (1) } \\
\hline \multicolumn{8}{|l|}{ Blue Pig Public House (1) } \\
\hline \multicolumn{8}{|l|}{ Bodleian Library (3) } \\
\hline \multicolumn{8}{|l|}{ Bodleian Library (13) } \\
\hline \multicolumn{8}{|l|}{ Brasenose College (34) } \\
\hline \multicolumn{8}{|l|}{ Britannia Inn (1) } \\
\hline \multicolumn{8}{|l|}{ Carfax Clock (1) } \\
\hline \multicolumn{8}{|l|}{ Central Girls School (1) } \\
\hline \multicolumn{8}{|l|}{ Christ Church Cathedral (11) } \\
\hline \multicolumn{8}{|l|}{ Christ Church Cathedral (3) } \\
\hline \multicolumn{8}{|l|}{ Christ Church College (7) } \\
\hline \multicolumn{8}{|l|}{ Christ Church College (23) } \\
\hline \multicolumn{8}{|l|}{ City Gaol (1) } \\
\hline \multicolumn{8}{|l|}{ City Walls (4) } \\
\hline Clarendon Building (2) & & & & & & & \\
\hline Corpus Christi College (23) & & & & & & & \\
\hline
\end{tabular}




\section{Continued}

Corpus Christi College (16)

County Hall (1)

Eastgate Hotel (5)

Examination Schools (5)

Exeter College (12)

Exeter College (22)

Frank Cooper's Works (2)

Frewin Hall (3)

Golden Cross Hotel (1)

Grandpoint Hall (1)

Hertford College (11)

Hertford College (17)

Holywell Chapel (1)

Indian Institute (3)

Jesus College (6)

Jesus College (6)

Jolly Farmers Inn (1)

Judges Lodgings (1)

Keble College (9)

Keble College (6)

Kemp Hall Police Station (3)

Lady Margaret Hall (2)

Lincoln College (16)

Lincoln College (7)

Magdalen College (98)

Magdalen College (46)

Magdalen College School (1)

Manchester College (2)

Mansfield College (2)

Mansfield College (5)

Medley Manor (2)

Merton College (38)

Merton College (21)

Morrells Brewery (1)

New College (38)

New College (19)

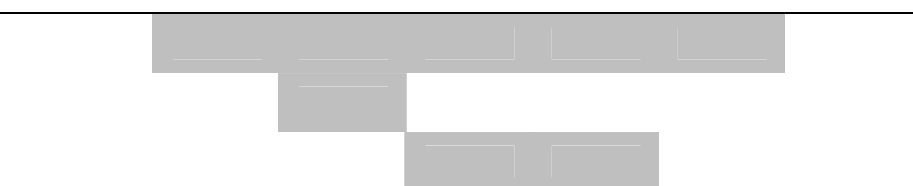


Continued

Old Ashmolean Museum (2)

Old Gate House Public House (1)

Old University Hall (4)

Old University Hall (2)

Oriel College (8)

Oriel College (11)

Oxford Castle (6)

Oxford Castle (5)

Oxford Times Offices (1)

Oxford Union (1)

Pembroke College (12)

Pembroke College (7)

Pusey House (2)

Queen's College (5)

Queen's College (13)

Radcliffe Camera (3)

Radcliffe Infirmary (3)

Radcliffe Science Library (1)

Randolph Hotel (1)

Randolph Hotel (1)

Roebuck Hotel (5)

Ruskin College (1)

Sheldonian Theatre (1)

Sheldonian Theatre (3)

Somerville College (2)

Somerville College (1)

St Aldates Church (2)

St Aloysius Church (1)

St Andrew's Church (1)

St Barnabas' Church (1)

St Bartholomew's Chapel (3)

St Bartholomew's Hospital (1)

St Cross Church (2)

St Cross Church (3)

St Ebbes Church (1)

St Ebbes Church (1)

St Edmund and St Frideswides Church (2)

St Edmund Hall (9)

St Edmund Hall (2) 


\section{Continued}

St George's Chapel (1)

St Giles' Church (1)

St Giles' Church (8)

St Giles House (2)

St Hildas College (8)

St Hildas College (1)

St Johns College (22)

St Johns Church (26)

St Martins Church (8)

St Mary Magdalens Church (1)

St Mary Magdalens Church (14)

St Mary the Virgin Church (9)

St Mary the Virgin Church (4)

St Marys Hall (1)

St Matthews Church (2)

St Michaels Church (7)

St Paul's Church (1)

St Peter in the East Church (6)

St Peter in the East Church (3)

St Peter Le Bailey Church (1)

St Peters College (1)

St Philip and St James Church (2)

St Philip and St James Church (1)

St Stephens House (1)

St Thomas Church (3)

Stones Almshouses (1)

Taylorian Institute (3)

Town Hall (6)

Trinity College (21)

Trinity College (17)

Turf Tavern (2)

University College (25)

University College (10)

University Museum (2)

University Museum (3)

Wadham College (6)

Wadham College (21)

Warneford Asylum (5)

Warneford Asylum (1)

Worcester College (49)

Worcester College (2)

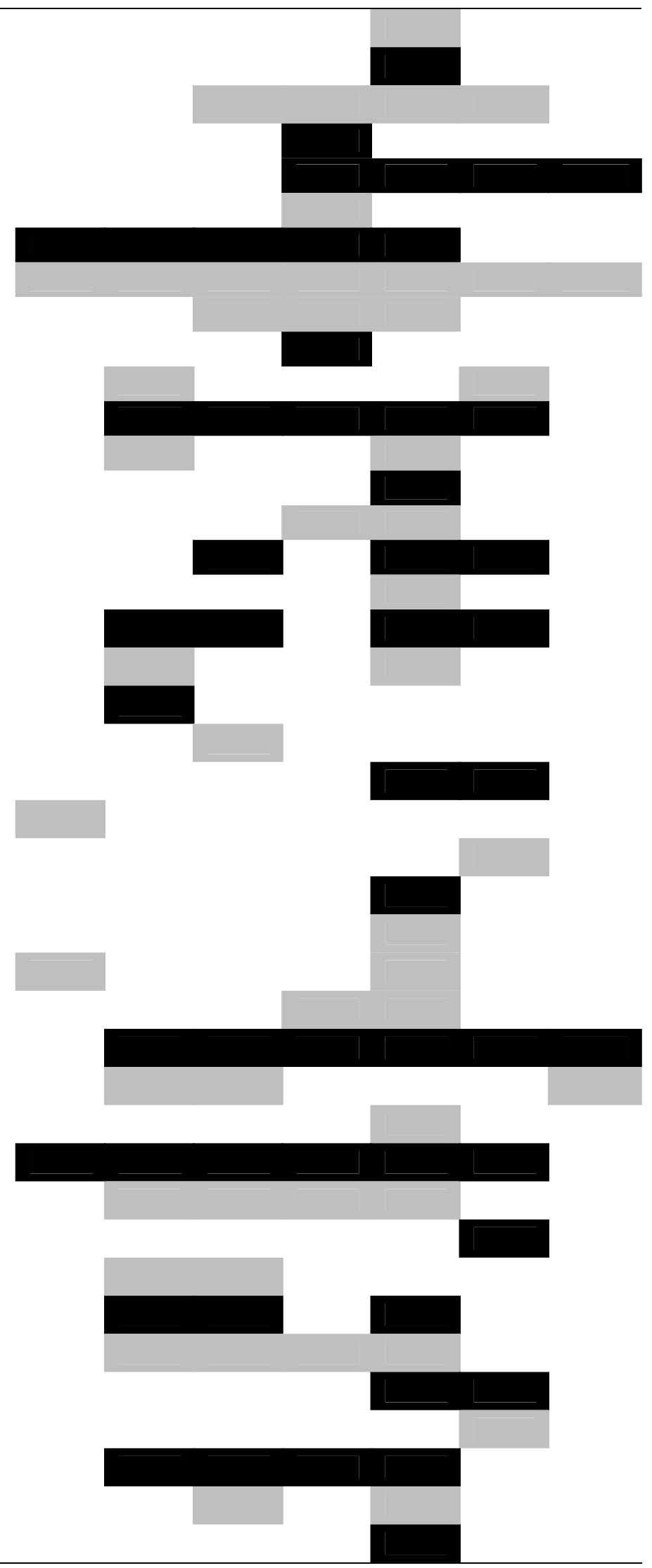

Wycliffe Hall (8) 
Magdalen College, St Edmund Hall, Trinity College, and University College, all of which are University colleges. Magdalen College had the most complete ivy/creeper cover of all properties examined in this study (it was also the most photographed in this record with 98 images). The earliest appearance of ivy/creeper (in the 1860s and 1870s) can be seen at All Souls College, Balliol College, Bodleian Library, Christ Church Cathedral, Christ Church College, Jesus College, Lincoln College, Magdalen College, Merton College, New College, Oriel College, Oxford Union, Pembroke College, Somerville College, St Edmund Hall, St Johns College, St Mary the Virgin Church, St Peter in the East Church, St Peter Le Bailey Church, Trinity College, University College, Wadham College, and Worcester College, which are mostly University properties.

A final analysis of the database results grouped all locations as either "town" or "gown". Counts appear in Table 3, and a $\chi^{2}$ test showed statistical significance to the 0.005 level. Most different from an equal probability were counts of no ivy/creeper in the "gown" sector, which was significantly less than expected. Table 3 generally conveys most counts for no ivy/creeper in the "town" (36) as well as ivy/creeper in the "gown" (33).

There are some limitations to these findings. These limitations regard image (record) and database quality. The first main issue affecting the former (record quality) is that of picture size and quality, as associated with too far a distance. More specifically, picture size and quality (with a dimension of approximately $700 \times 500$ pixels) posed limitations on the use of historical photographs in this study. In addition, another contributor to record quality is the lack of color (in the black and white photographs employed), which made it difficult to decipher (green) vegetation cover. Photographs without color made it more difficult to identify decay features and discriminate these from vegetation (especially in distant images). In order to resolve some of these issues associated with image (record) quality, images where building exteriors were blocked either by vegetation other than climbing plants or scaffolding were excluded; as were waterways, such as along the Cherwell, where it was difficult to make out climbing plants amongst other vegetation. Where buildings appear in the distance, and were too distant to make out details, they were also ex-

Table 3. Results of $\chi^{2}$ test $=13.5752>7.8795$ (critical value), $\mathbf{p}<0.005$.

\begin{tabular}{cccc}
\hline & Ivy/Creeper & No Ivy/Creeper & Total \\
\hline Town & $28(36)$ & $36(28)$ & 64 \\
Gown & $33(25)$ & $11(19)$ & 44 \\
Total & 61 & 47 & 108 \\
\hline
\end{tabular}

cluded, as at St Martin Carfax Church. Attempts were made to exclude any (climbing) vegetation that was not ivy/creeper (e.g., moss). In some cases, however, it was difficult to ascertain whether distant vegetation was indeed ivy/creeper rather than another type of climbing plant (as at Worcester College) or another type of vegetation altogether (such as decorative plants and flowers).

As for all other databases, the completeness of the record (database) needs to be questioned as well as whether all sides of building exteriors are represented photographically. However, comparisons including photographs where ivy/creeper is omitted help to portray a more complete record. Furthermore, since this study presents an overview of the ViewFinder database, it was not possible to develop specific case studies. It would be beneficial to compare print records of photographs from college photo archives (e.g., similar to work already completed for Magdalen College [3] as well as Trinity and Pembroke Colleges [6]; it is noteworthy that [2] was based on prints found in a published book and these images were derived from printed postcards that were derived from photographs taken at an earlier time and dated by stamp dates rather than actual photographic date as in the current study) in a comprehensive search for the appearance of ivy/creeper in the archival record. Solutions to these problems have been implemented in the execution of the research (in the Methods) and the error should be within $10 \%$ in view of these considerations and solutions.

\section{Conclusions}

This study using ViewFinder has found an abundance of archival photographs showing ivy/creeper on the exterior facades of buildings in central Oxford. Buildings were more often covered by climbing plants (more than half of the time), and some locations were more often clad with ivy/creeper than others, especially at University colleges, such as All Souls, Balliol, Magdalen (in particular), St Edmund Hall, Trinity, and University Colleges. More climbing plants appear in photographs in this digital archival record taken in the 1880s and 1900s. This is founded in comparisons made within the available record out of a total proportion (including photographs not depicting ivy/creeper) to account for biases in the photographic record. There are, however, several limitations to this study that have been outlined, considered, and remedied in this paper. The research is accurate, as conveyed by similar temporal trends (for Oxford colleges) found in previously published works, e.g. [6].

An important finding was the high representation of University colleges in the ViewFinder database and the observation that University colleges were often adorned in climbing plants (ivy/creeper), which perhaps warrants further research of case studies based on Oxford college 
photo archives. University buildings at large were more often covered with ivy/creeper than non-University properties, including churches and chapels, pubs, hotels, museums, the County and Town Halls, and so on. This was evident even though "gown" was less represented in this study than "town" locations. Statistical analysis using a $\chi^{2}$ test revealed that more ivy/creeper appeared on "gown" properties of the University (e.g. fewer than expected Oxford colleges were bare of ivy/creeper) and that "town" buildings were more often unclad with ivy/ creeper. This fundamental difference could be representative of a preference by the University of Oxford to allow for the growth of climbing plants on its buildings, possibly fostering a greener urban environment at an earlier date (in the 1860s and 1870s) than is evident in the City of Oxford. This preference could also be linked temporally to a Victorian tradition around 1837-1901 popularized in the 1880s and extended into the 1900s. Previous research based on postcard images, for instance, conveyed that between 1903 and 1923 Oxford colleges were clad in ivy/creeper. Other more recent studies (e.g., [6]) have conveyed a similar Victorian preference to climbing vegetation at Oxford colleges that was evident between 1880 and 1900 and reemerged more recently in the 1960s.

\section{Acknowledgements}

I am grateful to the staff at the Centre for Oxfordshire Studies for assisting me during my search for historical photographs and for suggesting that I try ViewFinder.

\section{REFERENCES}

[1] M. J. Thornbush, "Studies of Oxford Stone as a Contribution to Environmental Geomorphology," Journal of Environmental Geography, Vol. 6, No. 1-2, 2013, pp. 9-19.

[2] M. Thornbush, "Postcards used to Track Environmental History," Environmental History, Vol. 13, No. 2, 2008, pp. 360-365. doi:10.1093/envhis/13.2.360

[3] M. Thornbush and H. Viles, "The Changing Façade of Magdalen College, Oxford: Reconstructing Long-Term Soiling Patterns from Archival Photographs and Traffic Records," Journal of Architectural Conservation, Vol. 11, No. 2, 2005, pp. 40-57.

[4] H. A. Viles, "Time and Grime: Studies in the History of Building Stone Decay in Oxford," Research Paper No. 50, University of Oxford, Oxford, 1994, pp. 1-27.

[5] H. A. Viles, "The Environmental Sensitivity of Blistering of Limestone Walls in Oxford, England: A Preliminary Study," In: D. S. G. Thomas and R. J. Allison, Eds., Landscape Sensitivity, John Wiley and Sons Ltd., Chichester, 1993, pp. 308-326.

[6] M. J. Thornbush, "Tracking the Use of Climbing Plants in the Urban Landscape through the Photo Archives of Two Oxford Colleges, 1861-1964," Landscape Research, Vol.
38, No. 3, 2013, pp. 312-328.

[7] M. J. Thornbush and H. A. Viles, "Photographic Monitoring of Soiling and Decay of Roadside Walls in Oxford, England," Environmental Geology, Vol. 56, No. 3-4, 2008, pp. 777-787. doi:10.1007/s00254-008-1311-3

[8] M. J. Thornbush, "Photographic Surveys of Building Exteriors in Central Oxford, UK," International Journal of Architectural Heritage, Vol. 4, No. 4, 2010, pp. 351369. doi:10.1080/15583050903131355

[9] M. Thornbush and H. Viles, "Integrated Digital Photography and Image Processing for the Quantification of Colouration on Soiled Surfaces in Oxford, England," Journal of Cultural Heritage, Vol. 5, No. 3, 2004, pp. 285-290. doi:10.1016/i.culher.2003.10.004

[10] M. J. Thornbush and H. A. Viles, "Surface Soiling Pattern Detected by Integrated Digital Photography and Image Processing of Exposed Limestone in Oxford, England," In: C. Saiz-Jimenez, Ed., Air Pollution and Cultural Heritage, A. A. Balkema Publishers, London, 2004, pp. 221-224.

[11] M. J. Thornbush and H. A. Viles, "Photo-Based Decay Mapping of Replaced Stone Blocks on the Boundary Wall of Worcester College, Oxford," In: R. Prrikryl and B. J. Smith, Eds., Building Stone Decay: From Diagnosis to Conservation, Geological Society, London, 2007, pp. 69 75.

[12] M. Thornbush, "Grayscale Calibration of Outdoor Photographic Surveys of Historical Stone Walls in Oxford, England," Color Research and Application, Vol. 33, No. 1, 2008, pp. 61-67. doi:10.1002/col.20374

[13] M. J. Thornbush, "Measurements of Soiling and Colour Change Using Outdoor Rephotography and Image Processing in Adobe Photoshop along the Southern Façade of the Ashmolean Museum, Oxford," In: B. J. Smith, M. Gomez-Heras, H. A. Viles and J. Cassar, Eds., Limestone in the Built Environment: Present-Day Challenges for the Preservation of the Past, Geological Society, London, 2010, pp. 231-236.

[14] M. J. Thornbush, "Developing a Weathering Scale for Limestone Walls in Central Oxford, UK," Geosciences, Vol. 2, No. 4, 2012, pp. 277-297. doi:10.3390/geosciences2040277

[15] M. J. Thornbush and S. E. Thornbush, "The Application of a Limestone Weathering Index at Churchyards in Central Oxford, UK," Applied Geography, Vol. 42, Special Issue, 2013, pp. 157-164.

[16] M. J. Thornbush, "Digital Photography Used to Quantify the Greening of North-Facing Walls along Broad Street in Central Oxford, UK," Special Issue on Quantitative Geomorphology, Geomorphologie: Relief, Processus, Environment, No. 2, 2013, pp. 111-118.

[17] M. J. Thornbush, "Photogeomorphological Studies of Oxford Stone-A Review," Landform Analysis, in Press.

[18] M. J. Thornbush, "The Use of Climbing Plants in Heritage Bioconservation," In: Horizons in Earth Science Research, Volume 10, Nova Science Publishers, Hauppauge, in press. 